\title{
MENINGKATKAN KOMPETENSI GURU KELAS MELALUI PENDAMPINGAN BERBASIS KKG DALAM PENYUSUNAN RPP YANG BAIK DAN BENAR DI SD NEGERI 10 MATARAM SEMESTER DUA TAHUN PELAJARAN 2016/2017
}

\author{
Nizbiani \\ Kepala SD Negeri 10 Mataram.
}

\begin{abstract}
Abstrak. Penelitian ini dilaksanakan sebanyak dua siklus, masing-masing siklus dua kali pertemuan. Tahapan setiap siklus adalah perencanaan, pelaksanaan, pengamatan, dan refleksi. Indikator keberhasilan dalam penelitian ini adalah; 1) hasil observasi Kepala Sekolah maupun observasi guru selama proses pendampingan telah memperoleh skor rata-rata $\geq 4,0,2$ ) hasil kerja guru dalam penyusunan RPP mencapai $\geq 85 \%$ dengan nilai rata-rata $\geq 80,00$. Hasil penelitian pada siklus I observasi Kepala Sekolah rata-rata $(3,40)$, observasi guru rata-rata $(3,33)$ dan hasil kerja individual rata-rata nilai $(67,62)$ dengan prosentase ketercapaian $(0 \%)$. Pada siklus II observasi Kepala Sekolah rata-rata $(4,60)$, observasi guru rata-rata $(4,67)$ dan hasil kerja individual rata-rata nilai $(88,57)$ dengan prosentase ketercapaian (100\%). Indikator keberhasilan telah tercapai, penelitian di nyatakan berhasil dan dihentikan pada siklus II. Kesimpulan; pelaksanaan pendampingan dapat meningkatkan kompetensi guru sasaran SD Negeri 10 Mataram dalam penyusunan RPP yang baik dan benar. Disarankan agar Kepala Sekolah lainnya melakukan penelitian sejenis dalam upaya peningkatan kompetensi guru, dan kepada guru mata pelajaran agar mampu menyusun RPP dengan baik dan benar.
\end{abstract}

Kata Kunci : Pendampingan, KKG, RPP,

\section{PENDAHULUAN}

Kondisi nyata yang terjadi di SD Negeri 10 Mataram bahwa pada umumnya guru memiliki RPP bukan buatan sendiri, kecendrungan: 1) meminjam dari guru sekolah lain yang kondisi peserta didiknya tidak setara, sehingga RPP tidak tepat untuk dilakukan di sekolah, 2) copy paste dari internet walaupun isinya tidak sesuai dsengan tata cara penyusunan RPP yang baik dan benar, 3) menggunakan RPP yang berasal dari LKS, terbitan swasta yang kurang dapat dipertanggung jawabkan. Dari 6 (enam) guru kelas dalam penelitian ini setelah dipantau dan diadakan pengamatan terhadap RPP yang diserahkan kepada kepala sekolah dapat dijelaskan sebagai berikut: 3 orang yang mengcopy paste dari internet, 1 orang yang meminjam dari sekolah lain, 1 orang yang mengambil dari LKS dan 1 orang yang membuat sendiri.

Faktor penyebabnya adalah: 1) guru belum pernah mendapatkan bimbingan secara khusus bagaimana menyusun RPP yang baik dan benar dari kepala sekolah, 2) setiap guru mengajukan RPP untuk disyahkan oleh kepala sekolah tidak pernah disalahkan dan langsung ditanda tangani, 3) guru belum pernah mengikuti pendidikan dan pelatihan (Diklat) tentang penyusunan RPP yang baik dan benar, kalaupun ada yang pernah mengikuti kegiatannya kurang serius, di jadwalkan lima (5) hari kerja baru tiga hari sudah ditutup, 4) alasan klasik guru beralasan jumlah jam mengajarnya banyak sehingga tidak sempat untuk menyusun RPP, prinsipnya yang penting mengajar di kelas dengan berpedoman dengan buku paket siswa yang sudah disediakan oleh pihak sekolah dan oleh peserta didik itu sendiri.

Sebenarnya banyak solusi yang dapat dilakukan oleh kepala sekolah selaku peneliti, antara lain: 1) diadakan bimbingan/pendampingan khusus bagi guru kelas, 2) diadakan bintek khusus penyusunan RPP yang baik dan benar, 3) di galakkan pelaksanaan Kelompok Kerja Guru (KKG), dan lain-lain. Dalam penelitian ini kepala sekolah memilih melakukan pendampingan bagi 6 (enam) guru kelas melalui wadah KKG dalam upaya meningkatkan kompetensi guru kelas dalam menyusun RPP yang baik dan benar, 
semester dua tahun pelajaran 2016/2017 yang di pusatkan di SD Negeri 10 Mataram.

Ada beberapa keunggulan pelaksanaan sistem pendampingan berbasis KKG yakni: 1) melatih keberanian guru untuk berpendapat terhadap sesama guru, 2) pekerjaan yang berat bisa menjadi ringan, 3) menambah nilai kekeluargaan, kebersamaan, dan jiwa saling menolong, 4) bisa mengemukakan ide, gagasan, serta etos kerja yang berkualitas, dan 5) bisa merubah mindset guru dalam perencanaan proses pembelajaran dan sistem penilaian. Berdasarkan beberapa keunggulan dari proses pendampingan berbasis KKG, peneliti meyakini rendahnya kompetensi guru dalam penyusunan RPP yang baik dan benar dapat diminimalkan dan bahkan mampu meningkatkan kualitas proses dan hasil belajar peserta didik di kelas senyatanya.

Rumusan Masalah

"Bagaimana melaksanakan

pendampingan berbasis KKG untuk meningkatkan kompetensi guru dalam penyusunan RPP yang baik dan benar semester dua tahun pelajaran 2016/2017 di SD Negeri 10 Mataram?"

\section{Tujuan Penelitian}

"Untuk mengetahui efektifitas

pelaksanaan pendampingan secara klasikal dan individual berbasis KKG dalam upaya meningkatkan kompetensi guru dalam penyusunan RPP yang baik dan benar semester dua tahun pelajaran 2016/2017 di SD Negeri 10 Mataram."

\section{Manfaat Penelitian}

1. Bagi Kepala SD Negeri 10 Mataram; bermanfaat dalam upaya meningkatkan kompetensi guru dalam penyusunan RPP yang baik dan benar berdasarkan kurikulum 2007 (KTSP), melalui kegiatan pendampingan berbasis KKG.

2. Bagi guru SD Negeri 10 Mataram; bermanfaat dalam upaya penyusunan RPP yang baik dan benar, sehingga dapat diterapkan secara optimal dan terstruktur dalam proses pembelajaran di kelas senyatanya sesuai dengan spesifikasi bidang studi/mata pelajaran yang menjadi tanggung jawabnya.

\section{KAJIAN PUSTAKA Kompetensi Guru}

Guru memegang peranan dan tanggung jawab yang penting dalam pelaksanaan program pengajaran di sekolah. Guru merupakan pembimbing siswa sehingga keduanya dapat menjalin hubungan emosional yang bermakna selama proses penyerapan nilai-nilai dari lingkungan sekitar. Kondisi ini memudahkan mereka untuk menyesuaikan diri dalam kehidupan di masyarakat (Depdiknas, 2003 : 3).Kompetensi Guru; Kompetensi profesional guru menurut Sudjana (2002 : 17-19) dapat dikelompokkan menjadi tiga bidang yaitu pedagogik, personal dan sosial.

Menurut Murniati (2007 : 2) salah satu ciri dari profesi dituntut memiliki kecakapan yang memenuhi persyaratan yang telah dibakukan oleh pihak yang berwewenang (standar kompetensi guru). Istilah kompetensi diartikan sebagai perpaduan antara pengetahuan, ketrampilan, sikap dan nilai-nilai yang diwujudkan dalam pola berpikir dan bertindak atau sebagai seperangkat tindakan cerdas dan penuh tanggung jawab yang dimiliki seseorang sebagai syarat untuk dianggap mampu oleh masyarakat dalam melaksanakan tugas-tugas sesuai dengan pekerjaan tertentu. Berdasarkan Peraturan Pemerintah Nomor 19 Tahun 2005 tentang Standar Nasional Pendidikan, guru harus memiliki kompetensi pedagogik, kepribadian, profesional, dan sosial (Depdiknas, 2005 : 24, 90 - 91).

1. Kompetensi pedagogik merupakan kemampuan yang berkenaan dengan pemahaman peserta didik dan pengelola pembelajaran yang mendidik dan dialogis. Secara substantif kompetensi ini mencakup kemampuan pemahaman terhadap peserta didik, perancangan dan pelaksanaan pembelajaran, evaluasi hasil belajar, dan pengembangan peserta didik untuk mengaktualisasikan berbagai potensi yang dimilikinya.

2. Kompetensi kepribadian merupakan kemampuan personal yang mencerminkan kepribadian yang mantap, arif, dewasa, dan berwibawa, menjadi teladan bagi peserta didik, dan berakhlak mulia. 
3. Kompetensi profesional merupakan kemampuan yang berkenaan dengan penguasaan materi pembelajaran bidang studi secara luas dap mendalam yang mencakup penguasaan substansi isi materi kurikulum matapelajaran di sekolah dan substansi keilmuan yang menaungi materi kurikulum tersebut, serta menambah wawasan keilmuan sebagai guru.

4. Kompetensi sosial berkenaan dengan kemampuan pendidik sebagai bagian dari masyarakat untuk berkomunikasi dan bergaul secara efektif dengan peserta didik, sesama pendidik, tenaga kependidikan, orangtua/wali peserta didik, dan masyarakat sekitar.

Yang dimaksud dengan kompetensi guru dalam penelitian tindakan sekolah (PTS) ini adalah kemampuan 6 (enam) guru kelas dalam penyusunan Rencana Pelaksanaan Pembelajaran (RPP) yang baik dan benar. Adapaun ciri-ciri RPP dikatakan baik dan benar adalah: 1) memuat aktifitas proses belajar mengajar yang akan dilaksanakan oleh guru dan menjadi pengalaman belajar bagi peserta didik, 2) langkah-langkah pembelajaran disusun secara sistematis agar tujuan pembelajaran dapat dicapai, 3) langkah-langkah pembelajaran disusun serinci mungkin, sehingga apabila RPP digandakan guru lain (misalnya, ketiga guru mata pelajaran tidak hadir) mudah dipahami dan tidak menimbulkan penafsiran ganda.

\section{Pendampingan}

Pendampingan adalah sebuah bentuk hubungan yang memungkinkan terjadinya proses berbagi keterampilan dan pengalaman baik professional, maupun personal yang mendorong proses tumbuh dan berkembang sepanjang proses yang terjadi. Pendampingan merupakan bentuk hubungan antar personal antara seseorang yang dipandang lebih berpengalaman atau lebih professional dan seseorang yang diposisikan masih kurang berpengalaman atau kurang professional. Proses pendampingan didasarkan pada pemberian dorongan, komentar dan saran yang bersifat membangun, terlaksana dalam suasana keterbukaan, saling percaya dan saling menghargai, serta keinginan yang kuat untuk berbagi dan belajar satu sama lain. Keseluruhan proses dan semua aspek pendampingan terjadi karena hubungan yang terjalin antara pihak yang terlibat dalam pendampingan adalah hubungan yang sudah lama terbangun.

Pada dasarnya, konsep mentoring mencakup tiga komponen, yaitu: pendamping, yang terdampingi, dan proses pendampingan. Pendamping bisa seorang guru, sponsor, konselor, penasehat, teman sejawat, pendukung, orang kepercayaan, atau model. Yang terdampingi biasanya adalah seseorang yang masih pemula dan digambarkan sebagai mitra peserta dalam proses pendampingan. Proses pendampingan adalah pengembangan hubungan antara pendamping dan yang terdampingi. Definisi pendampingan sangat beragam tergantung pada strategi yang digunakan. Secara umum, pendampingan adalah proses yang melibatkan seseorang yang lebih berpengalaman, profesional, pakar untuk memberikan dukungan, bimbingan, dan nasehat kepada, serta berbagi pengalaman dengan rekan yang kurang berpengalaman.

Dalam wujudnya yang paling efektif, pendampingan adalah kemitraan pembelajaran yang melibatkan kerjasama dan peluang untuk menghadapi tantangan dan melakukan refleksi berkelanjutan oleh kedua belah pihak yang terlibat. Hubungan pendampingan bisa juga berupa kemitraan sejawat yang di dalamnya, posisi dan peran pendamping dan yang terdampingi bisa saja bertukar berdasarkan konteks tertentu.

Yang dimaksud dengan pendampingan dalam penelitian tindakan sekolah (PTS) ini adalah kepala SD Negeri 10 Mataram selaku peneliti membimbing/mendampingi terhadap 6 (enam) guru kelas dalam penyusunan RPP yang baik dan benar. Dalam pelaksanaannya pendampingan dilakukan melalui 2 (dua) tahapan. Tahap I semua guru dikumpulkan untuk mendapatkan penjelasan teknik tata cara penyusunan RPP yang baik dan benar sesuai dengan bidang studi/mata pelajaran yang diampunya. Tahap II yaitu pendampingan individual, dimana peneliti mendampingi secara individu dalam kelompok kecil untuk 
menjelaskan lebih rinci tata cara menyusun RPP yang baik dan benar.

\section{Kelompok Kerja Guru (KKG)}

Trimo (2007: 12) Kelompok Kerja Guru yaitu suatu organisasi profesi guru yang bersifat struktural yang dibentuk oleh guru-guru di suatu wilayah atau gugus sekolah sebagai wahana untuk saling bertukaran pengalaman guna meningkatkan kemampuan guru dan memperbaiki kualitas pembelajaran.

Menurut Buchari Zainun 1987 (dalam, Suryosubroto 2004: 1) ada lima faktor yang mendasari kegiatan manusia dalam organisasi yaitu:

a. Faktor spesialisasi dan pembagian kerja;

b. Faktor koordinasi;

c. Faktor tujuan;

d. Faktor prosedur kerja;

e. Faktor dinamika lingkungan.

Melalui KKG guru memiliki kesempatan dan berpotensi mendiskusikan penyelesaian permasalahan yang dihadapi di kelas. Trimo (2007: 12) menyatakan, "pembinaan melalui KKG memberikan kesempatan bagi guru yang lebih luas (dimungkinkan semua guru terlibat), dibanding bentuk pembinaan yang lain (harus menunggu kesempatan)". Uceh Nurabnu (2012: 24) Gugus TK merupakan wadah kegiatan Kelompok Kerja Guru (KKG) dan Kelompok Kerja Kepala TK (KKKTK) yang telah ditetapkan melalui Direktur Jendral Pendidikan Dasar dan Menengah, Departemen Pendidikan dan Kebudayaan Nomor 086/c/Kep/v/tanggal 8 Mei 1995.

Direktorat Pembinaan TK dan SD, Sriwasono (2010: 2) menyatakan, "tujuan umum mengembangkan kegiatan di KKG dan KKG untuk meningkatkan mutu pembelajaran sesuai dengan standar pelayanan pendidikan dalam kerangka penjaminan mutu pendidikan nasional".

Menurut Standar Pengembangan KKG Derektorat Profesi Pendidik Direktorat Jendral Peningkatan Mutu Pendidikan dan Tenaga Kependidikan Departemen Pendidikan dan Kebudayaan Republik Indonesia, tujuan KKG adalah: a. Memperluas wawasan dan pengetahuan guru dalam berbagai hal, khususnya penguasaan substansi materi pembelajaran, penyusunan silabus, penyusunan bahanbahan pembelajaran, strategi pembelajaran, metode pembelajaran, memaksimalkan pemakaian sarana/prasarana belajar, memanfaatkan sumber belajar, dsb

b. Memberikan kesempatan kepada anggota kelompok kerja atau musyawarah kerja untuk berbagi pengalaman serta saling memberikan bantuan dan umpan balik;

c. Meningkatkan pengetahuan dan keterampilan, serta mengadopsi pendekatan pembaharuan dalam pembelajaran yang lebih profesional bagi peserta kelompok kerja atau musyawarah kerja;

d. Memberdayaan dan membantu anggota kelompok kerja dalam melaksanakan tugas-tugas pembelajaran di sekolah;

e. Mengubah budaya kerja anggota kelompok kerja atau musyawarah kerja (meningkatkan pengetahuan, kompetensi dan kinerja) dan mengembangkan profesionalisme guru melalui kegiatankegiatan pengembangan profesionalisme di tingkat $\mathrm{KKG}$;

f. Meningkatkan mutu proses pendidikan dan pembelajaran yang tercermin dari peningkatan hasil belajar peserta didik;

g. Meningkatkan kompetensi guru melalui kegiatan-kegiatan di tingkat KKG.

Yang dimaksud dengan kelompok kerja guru (KKG) dalam penelitian ini adalah 6 (enam) guru SD Negeri 10 Mataram yang menjadi sasaran dalam pelaksanaan pendampingan dalam penyusunan RPP berdasarkan Kurikulum 2006 (KTSP). Kegiatan nyata KKG SD Negeri 10 Mataram yaitu penysunan Rencana Pelaksanaan Pembelajaran )RPP) yang dibimbing langsung oleh kepala sekolah selaku peneliti. Dalam kegiatan ini semua guru kelas dari kelas I sampai dengan guru kelas VI menyusun RPP secara individualdalam forum KKG. Kendala/kesulitan yang dialami oleh guru langsung diberikan bimbingan, perbaikan, dan penyempurnaan sesuai dengan situasi dan 
kondisi pada saat KKG yang diselenggarakan di SD Negeri 10 Mataram.

\section{Rencana Pelaksanaan Pembelajaran (RPP)}

Pada hakekatnya penyusunan RPP bertujuan merancang pengalaman belajar siswa untuk mencapai tujuan pembelajaran. Tidak ada alur pikir (algoritma) yang spesifik untuk menyusun suatu RPP, karena rancangan tersebut seharusnya kaya akan inovasi sesuai dengan spesifikasi materi ajar dan lingkungan belajar siswa (sumber daya alam dan budaya lokal, kebutuhan masyarakat serta perkembangan ilmu pengetahuan dan teknologi). Pengalaman dari penilaian portofolio sertifikasi guru ditemukan, bahwa pada umumnya RPP guru cenderung bersifat rutinitas dan kering akan inovasi. Mengapa? diduga dalam melakukan penyusunan RPP guru tidak melakukan penghayatan terhadap jiwa profesi pendidik. Keadaan ini dapat dipahami karena, guru terbiasa menerima borang-borang dalam bentuk format yang mengekang guru untuk berinovasi dan penyiapan RPP cenderung bersifat formalitas. Bukan menjadi komponen utama untuk sebagai acuan kegiatan pembelajaran. Sehingga ketika otonomi pendidikan dilayangkan tak seorang gurupun bisa mempercayainya. Buktinya perilaku menyusun RPP dan perilaku mengajar guru tidak berubah jauh.

Acuan alur pikir yang dapat digunakan sebagai alternatif adalah:

1. Kompetensi apa yang akan dicapai.

2. Indikator-indikator yang dapat menunjukkan hasil belajar dalam bentuk perilaku yang menggambarkan pencapaian kompetensi dasar.

3. Tujuan pembelajaran yang merupakan bentuk perilaku terukur dari setiap indikator.

4. Materi dan uraian materi yang sesuai dengan kebutuhan belajar siswa agar ianya dapat mencapai tujuan pembelajaran.

5. Metode-metode yang akan digunakan dalam pembelajaran.

6. Langkah-langkah penerapan metodemetode yang dipilih dalam satu kemasan pengalaman belajar.
7. Sumber dan media belajar yang terkait dengan aktivitas pengalaman belajar siswa.

8. Penilaian yang sesuai untuk mengukur ketercapaian tujuan pembelajaran.

Secara umum, ciri-ciri Rencana Pelaksanaan Pembelajaran (RPP) yang baik adalah sebagai berikut:

1. Memuat aktivitas proses belajar mengajar yang akan dilaksanakan oleh guru yang akan menjadi pengalaman belajar bagi siswa.

2. Langkah-langkah pembelajaran disusun secara sistematis agar tujuan pembelajaran dapat dicapai.

3. Langkah-langkah pembelajaran disusun serinci mungkin, sehingga apabila RPP digunakan oleh guru lain (misalnya, ketiga guru mata pelajaran tidak hadir), mudah dipahami dan tidak menimbulkan penafsiran ganda.

\section{Kerangka Konseptual}

Variabel harapan dalam penilaian ini adalah meningkatnya kompetensi 6 (enam) guru kelas dalam penyusunan RPP yang baik dan benar, sedangkan variabel tindakan dalam penelitian iniadalah melaksanakan pendampingan secara klasikal (kelompok besar) dan pendampingan individual (kelompok kecil/perorangan) berbasis KKG.

\section{Hipotesis Tindakan}

"jika pendampingan dilaksanakan dengan baik, maka kompetensi guru dalam penyusunan RPP yang baik dan benar bagi guru kelas SD Negeri 10 Mataram semester dua tahun pelajaran 2016/2017 dapat di tingkatkan" METODE PENELITIAN

\section{Setting Penelitian}

Penelitian Tindakan Sekolah (PTS) ini dilaksanakan di SD Negeri 10 Mataram yang pelaksanaannya melalui kegiatan pendampingan berbasis KKG bagi 6 (enam) guru kelas dalam penyusunan RPP yang baik dan benar yang dilaksanakan dalam forum KKG sekolah.

\section{Jenis Tindakan dan Dampak yang} diharapkan

- Jenis Tindakan : pendampingan berbasis KKG dalam penyusunan RPP yang baik dan benar bagi 6 (enam) guru kelas di SD 
Negeri 10 Mataram semester dua tahun pelajaran 2016/2017

- Dampak yang diharapkan :

Meningkatnya kompetensi 6 (enam) guru kelas dalam penyusunan RPP yang baik dan benar.

\section{Perencanaan Tindakan}

\section{Jenis tindakan yang dilakukan}

Untuk mendapatkan gambaran riil tentang skenario pelaksanaan tindakan pada kegiatan pendampingan berbasis KKG ini dapat di gambarkan sebagai berikut:

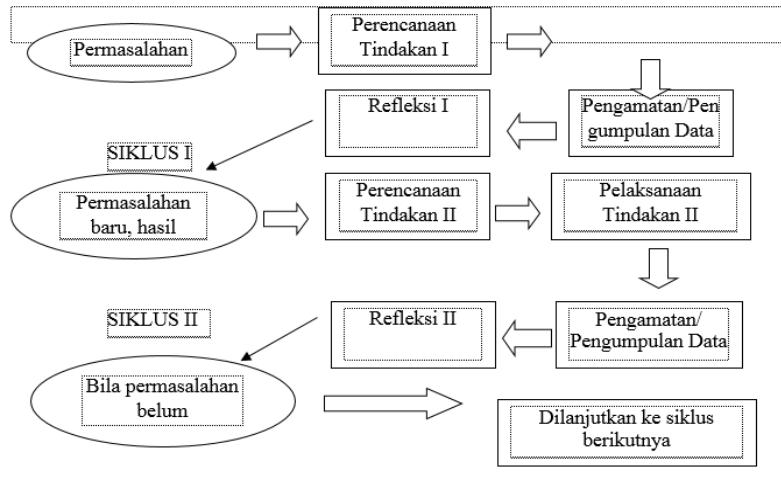

(Suharjono, 2009)

\section{Pelaksanaan Tindakan}

Pelaksanaan tindakan yang meliputi deskripsi tindakan yang dilakukan meliputi pelaksanaan rencana tindakan yang telah disiapkan, termasuk didalamnya langkahlangkah pelaksanaan atau praktik kepengawaasan di sekolah dalam setiap siklus (Suharjono, 2009). Dalam kegiatan ini peneliti melakukan kegiatan pendampingan penyusunan Rencana Pelaksanaan Pembelajaran (RPP) berdasarkan kurikulum 2007 dengan berpedoman pada perencanaan pendampingan yang telah di tetapkan.

\section{Evaluasi dan Refleksi Tindakan}

Pada tahapan ini peneliti melakukan kajian dan penelitian proses tindakan dan hasil atau dampak tindakan terhadap perubahan perilaku sasaran (nana Sujana, 2009:39). Adapun kegiatan riilnya adalah: 1) membandingkan hasil pengamatan pelaksanaan kerja kelompok/diskusi yang difokuskan kegiatan penyusunan RPP yang baik dan benar berdasarkan kurikulum 2007, 2) membandingkan hasil kerja individual dari 6 (enam) guru kelas dalam penyusunan RPP dengan indikator keberhasilan yang telah ditetapkan.

\section{Siklus Tindakan}

Dalam penelitian ini di rencanakan sebanyak 2 (duaa) siklus, masing-masing siklus 1 (satu) kali pertemuan dengan agenda 2 (dua) kegiatan secara terpadu yaitu pendampingan klasikal/kelompok besar dan pendampingan individual/kelompok kecil. Kegiatan masingmasing siklus terdiri dari 4 (empat) tahapan yaitu perencanaan, pelaksanaan, observasi, dan refleksi. Untuk mendapatkan gambaran secara rinci kegiatan masing-masing tahapan dapat di jelaskan sebagai berikut:

\section{SIKLUS I}

\section{Tahap I : Perencanaan Tindakan}

1.1. Menyusun materi pendampingan

1.2. Menetapkan scenario dan langkahlangkah pendampingan yang tertuang dalam Rencana Pelaksanaan pendampingan (RPP)

1.3. Menyusun instrument observasi kepala sekolah dan observasi guru

1.4. Menentukan jadwal kegiatan pendampingan

1.5. Menyusun pedoman analisa data hasil observasi dan tugas individu.

Tahap II. Pelaksanaan Tindakan

2.1. Menyampaikan materi tentang tata cara penyusunan RPP yang baik dan benar.

2.2. Melaksanakan diskusi kelompok kecil dalam penyusunan RPP.

2.3. Memberikan bimbingan secara berkelompok/perorangan.

2.4. Memberikan solusi terhadap permasalahan yang dihadapi oleh guru

2.5. Memberikan penguatan/reward

2.6. Memberikan tugas individual.

Pada kegiatan pendampingan individual yang dilakukan secara bergiliran, dengan cara peneliti mendekati guru satu persatu dalam kelompok untuk membimbing secara individual agar permasalahan-ppermasalahan dapat dipecahkan dengan baik dan benar.

Tahap III. Observasi/pengumpulan Data

3.1. Pengamatan terhadap aktifitas guru peserta pendampingan

3.2. Pengamatan terhadap kinerja guru dalam penyusunan RPP yang baik dan benar. 
3.3. Menilai hasil kerja guru secara individual

Tahap IV. Refleksi

4.1. Renungan atas data hasil observasi dan hasil kerja secara individual.

4.2. Pengolahan data hasil penelitian dan mencocokkan dengan indikator keberhasilan.

4.3. Rencana perbaikan dan penyempurnaan

4.4. Memberikan penguatan atas hasil yang diperolehnya.

4.5. Rencana tindak lanjut.

\section{SIKLUS II}

Jenis kegiatan pada siklus II ini pada dasarnya sama dengan siklus I, bedanya hanya terjadi perbaikan/penyempurnaan dalam pelaksanaannya.

\section{Indikator Keberhasilan}

1. Hasil observasi kepala sekolah maupun observasi guru peserta pendampingan telah mencapai skor rata-rata $\geq 4,0$ (Kategori baik).

2. Hasil kerja secara individual penyusunan RPP yang baik dan benar berdasarkan kurikulum 2007 dinyatakan telah berhasil jika mencapai $\geq 85 \%$ dengan nilai rata-rata $\geq 80,00$ (Kategori Baik).

\section{LAPORAN HASIL DAN PEMBAHASAN}

Pada tahapan ini peneliti melakukan: 1) menyusun materi pendampingan, 2) menetapkan skenario dan langkah-langkah pendampingan yang tertuang dalam Rencana Pelaksanaan Pendampingan (RPP), 3) menyusun instrumen observasi kepala sekolah dan instrumen observasi guru, 4) menentukan jadwal kegiatan pendampingan, dan 5) menyusun pedoman analisis data

\section{Tahap Pelaksanaan}

- Pendampingan klasikal/kelompok; 1) menyampaikan materi tentang tata cara penyusunan RPP yang baik dan benar, 2) melaksanakan diskusi kelompok kecil dalam penyusunan RPP, 3) memberikan bimbingan secara berkelompok, 4) memberikan solusi terhadap permasalahan yang dihadapi oleh guru, 5) memberikan penguatan/reward, dan 6) memberikan tugas individual.

- Pendampingan individual, jenis kegiatannya adalah; 1) pada saat guru bekerja dalam kelompok/diskusi kelompok peneliti membimbing guru yang mengalami kesulitan dalam penyusunan RPP secara kelompok kecil/perorangan, 2) memberikan solusi/pemecahan terhadap kesulitan yang dirasakan secara individual, 3) kegiatan seterusnya sampai ke 6 (enam) guru peserta pendampingan mendapatkan giliran pendampingan secara individual

\section{Tahap Observasi}

Observasi kepala sekolah memperoleh skor rata-rata sebesar 3,40, Hasil Observasi Guru memperoleh skor rata-rata sebesar 3,33, dan Nilai Individual hasil penyusunan RPP yang baik dan benar memperoleh nilai rata-rata sebesar 67,62.

\section{Tahap Refleksi}

Pada tahapan ini peneliti merenung atas perolehan data hasil observasi kepala sekolah, observasi guru, dan nilai individual hasil penyusunan RPP yang baik dan benar. Selanjutnya peneliti mengolah data dan hasilnya di cocokkan dengan indikator keberhasilan. Karena perolehan hasil masih dibawah indikator keberhasilan yang direncanakan, maka pada siklus berikutnya akan diadakan perbaikan dan penyempurnaan dari serangkaian kegiatan pendampingan secara klasikal maupun secara individual, namun demikian peneliti tetap memberikan penguatan atas hasil yang diperolehnya dan penelitian dilanjutkan pada siklus II dengan mengoptimalkan semua jenis tindakan dalam pendampingan sehingga di peroleh hasil yang memuaskan.

\section{Deskripsi Siklus II \\ Tahap Perencanaan}

Tahapan perencanaan pada siklus II jenis kegiatannya masih sama dengan siklus I, bedanya pada siklus II ini lebih memfokuskan perbaikan/penyempurnaan dalam proses pendampingan klasikal maupun pendampingan individual, yang jenis kegiatannya adalah: 1) menyempurnakan materi pendampingan, 2) menetapkan skenario pendampingan, 3) menetapkan instrumen observasi kepala sekolah maupun observasi guru, 4) menetapkan jadwal kegiatan pendampingan, 5) menyusun pedoman analisis data hasil observasi dan tugaas individu. 


\section{b. Tahap Pelaksanaan}

- Pendampingan klasikal/kelompok; 1) menyampaikan/merefleksi hasil perolehan data pada siklus I, 2) menjelaskan ulang tata cara penyusunan RPP yang baik dan benar secara lebih rinci, 3) perbaikan RPP secara berkelompok/diskusi kelompok, memberikan refleksi terhadap hasil kerja kelompok yang mengalami kendala, 5) memberikan penghargaan/reward dan 6) memberikan tugas individual.

- Pendampingan individual/kelompok kecil; 1) pada saat proses kerjasama dalam kelompok, peneliti mengamati/mencermati hasil kerja secara individual, 2) memberikan bimbingan/merefleksi terhadap hasil kerja individual yang masih mengalami kendala, 3) begitu seterusnya sampai semua guru peserta pendampingan mendapatkan pendampingan secara individual.

\section{Tahap Observasi/Pengumpulan Data}

Observasi kepala sekolah memperoleh skor rata-rata sebesar 4,60, Hasil Observasi Guru memperoleh skor rata-rata sebesar 4,67, dan Nilai Individual hasil penyusunan RPP yang baik dan benar memperoleh nilai rata-rata sebesar 88,57.

\section{Tahap Refleksi}

Pada tahapan ini peneliti merenung atas perolehan data hasil observasi kepala sekolah, observasi guru, dan nilai individual hasil penyusunan RPP yang baik dan benar. Kemudian di olah engan menggunakan rumus yang telah ditetapkan. Karena perolehan hasil siklus II sudah melebihi indikator keberhasilan, maka tidak perlu ada perbaikan/penyempurnaan dalam penyusunan RPP yang baik dan benar, selanjutnya peneliti memberikan penghargaan/reward kepada semua guru peserta pendampingan karena dari 6 (enam) guru kelas $100 \%$ sudah memperoleh nilai rata-rata $\geq$ 80,00. Penelitian dinayatakan berhasil dan tindakan dihentikan pada siklus II.

\section{Pembahasan}

\section{SIKLUS I}

\section{Tahap Perencanaan}

banyak kendala yang dihadapi peneliti diantaranya: dalam menetapkan skenario dan langkah-langkah pendampingan, perencanaan penyusunan instrumen observasi kepala sekolah dan instrumen observasi guru, tetapi setelah meminta petunjuk kepada pembimbing akhirnya kendala pun bisa diatasi.

\section{Tahap Pelaksanaan}

Kegiatan nyata dalam pelaksanaan pendampingan dapat dijabarkan sebagai berikut: pada saat menyampaikan materi tentang tata cara penyusunan RPP yang baik dan benar mengalami kendala yang disebabkan peneliti masih kekurangan sumber/buku literatur, sehingga berdampak tertundanya dalam penyusunan, solusi yang dilakukan peneliti mencari beberapa buku literatur terkait dengan tata cara penyusunan RPP termasuk mencari di internet, akhirnya materi pendampingan dapat tersusun dengan baik.

Dalam pelaksanaan bimbingan pada saat peserta pendampingan melakukan diskusi/kerjasama dalam kelompok, peneliti berkeliling memberikan bimbingan dan solusi terhadap peserta yang mengalami kesulitan. Pada kegiatan ini peneliti tidak mengalami hambatan/permasalahan artinya berjalan sesuai dengan rencana.

\section{Tahap Observasi/Pengumpulan Data}

Hasil perolehan skor/nilai selama pendampingan pada siklus I peneliti memperoleh skor rata-rata $(3,40)$ dari indikator keberhasilan yang direncanakan yaitu $\geq 4,0$. Perolehan skor rata-rata aktifitas peserta pendampingan pada siklus I yaitu $(3,33)$ dari indikator keberhasilan $(\geq 4,0)$. Perolehan nilai rata-rata hasil kerja guru dalam penyusunan RPP yang baik dan benar secara individual memperoleh rata-rata $(67,62)$ dari indikator keberhasilan $\geq 80,0$ (kategori baik). Dari 6 (enam) guru peserta pendampingan pada siklus I belum ada satu guru pun yang dinyatakan memperoleh nilai rata-rata $\geq 80,00$. Ini artinya pada siklus I presentasi pencapaian hasil kerja individual masih 0, dalam arti belum ada yang tuntas sesuai indikator yang telah ditetapkan. Pada kegiatan siklus berikutnya peneliti harus mampu memotivasi peserta pendampingan dalam upaya mencapai indikator keberhasilan sebagai dampak nyata dari hasil pendampingan. 


\section{Tahap Refleksi}

Perolehan skor rata-rata hasil observasi kepala sekolah selama proses pendampingan baru memperoleh skor rata-rata $(3,40)$, sementara perolehan hasil observasi peserta pendampingan sebagai aktifitas peserta selama pendampingan baru memperoleh skor rata-rata $(3,33)$, dan nilai rata-rata hasil penyusunan RPP yang baik dan benar baru mencapai nilai ratarata $(67,62)$. Dari perolehan hasil dimaksud peneliti merenung mencari faktor kendala dan penyebab sehingga hasil masil belum optimal. Dari hasil renungan itu akhirnya peneliti menemukan solusi untuk dapat dilaksanakan pada kegiatan pendampingan siklus berikutnya.

\section{SIKLUS II}

\section{Tahap Perencanaan}

Kesalahan-kesalahan yang terjadi pada siklus I sudah diperbaiki pada siklus II, sehingga pada tahapan ini peneliti bisa melakukan dengan baik. Kegiatan pada tahap perencanaan ini meliputi; 1) penyempurnaan penyusunan materi pendampingan, 2) perbaikan skenario/strategi/langkah-langkah

pendampingan yang mengarah kepada peserta aktif, 3) menetapkan instrumen observasi kepala sekolah dan instrumen observasi guru, 4) menentukan jadwal kegiatan dan menetapkan pedoman analisa data hasil observasi dan hasil kerja individual.

\section{Tahap Pelaksanaan}

Pada tahapan ini, peneliti terlebih dahulu melakukan refleksi atas capaian hasil yang diperoleh pada siklus I. Kendala-kendala dan permasalahan yang terjadi dibahas sampai semua peserta pendampingan memahami dan menyadari akan kekurangan, kesalahan dan halhal yang bersifat krusial dapat dipecahkan pada saat kegiatan refleksi.Kegiatan selanjutnya peneliti menyampaikan materi pendampingan secara perlahan-lahan, ringkas dan jelas sehingga peserta pendampingan lebih paham dan mengerti tata cara penyusunan RPP yang baik dan benar.

\section{Tahap Observasi}

Pada siklus II perolehan skor rata-rata hasil observasi kepala sekolah adalah $(4,60)$ dari indikator keberhasilan $\geq 4,00$, ini artinya menunjukkan peningkatan yang sangat signifikan bila dibandingkan dengan perolehan hasil pada siklus I. Skor rata-rata hasil observasi guru yaitu aktifitas selama pendampingan dalam forum KKG memperoleh skor rata-rata $(4,67)$ dari indikator keberhasilan $\geq 4,00$. Dari hasil ini nampak nyata bahwa aktifitas peserta pendampingan pada siklus II mengalami peningkatan yang sangat tajam karena sudah mampu melampaui indikator keberhasilan yang telah ditetapkan. Nilai ratarata hasil kerja individual dalam penyusunan RPP yang baik dan benar yakni $(88,57)$ dari indikator keberhasilan $(\geq 80,00)$.

\section{Tahap Refleksi}

Berdasarkan hasil akhir perolehan skor rata-rata observasi kepala sekolah dan observasi guru serta hasil kerja individual penyusunan RPP yang baik dan benar semuanya telah melampaui indikator keberhasilan maka dapat disimpulkan bahwa: 1) upaya untuk menyempurnakan materi pendampingan dinyatakan berhasil, 2) pelaksanaan untuk memperbaiki strategi penyampaian materi tata cara penyusunan RPP dan strategi pendampingan telah mampu meningkatkan motivasi dan kinerja guru sehingga perolehan hasil yang diharapkan dapat tercapai, 3) upaya untuk mengoptimalkan pelaksanaan pendampingan individual telah membawa dampak positif terhadap perolehan hasil dalam penyusunan RPP yang baik dan benar.

Karena semua indikator keberhasilan telah tercapai maka penelitian tindakan sekolah dihentikan pada siklus II dan dinyatakan berhasil memotivasi guru untuk lebih bergairah dan lebih bersemangat dalam upaya penyusunan RPP yang baik dan benar. Penelitian Tindakan Sekolah dengan judul "Meningkatkan Kompetensi Guru Kelas Melalui Pendampingan Berbasis KKG Dalam Penyusunan RPP Yang Baik Dan Benar Di SD Negeri 38 Cakranegara Semester Dua Tahun Pelajaran 2016/2017", dinyatakan "Berhasil". 


\section{KESIMPULAN}

Perolehan data selama penelitian dapat dipaparkan sebagai berikut:

\begin{tabular}{|c|c|c|c|c|c|c|}
\hline \multirow{2}{*}{$\mathrm{N}_{0}$} & \multirow{2}{*}{ Jenis Kegiatan } & \multirow{2}{*}{$\begin{array}{c}\text { Indikator } \\
\text { Keberhasilan }\end{array}$} & \multicolumn{2}{|c|}{ Perolehan } & \multirow{2}{*}{ Peningkatan } & \multirow{2}{*}{ Ket } \\
\hline & & & Siklus I & Siklus II & & \\
\hline 1. & $\begin{array}{l}\text { Hasil Observasi Kepala } \\
\text { Sekolah }\end{array}$ & $\geq 4,00$ & 3,40 & 4,60 & 1,20 & Tuntas \\
\hline 2. & Hasil Observasi Guru & $\geq 4,00$ & 3,33 & 4,67 & 1,34 & Tuntas \\
\hline 3. & Hasil Keria Individual & $\geq 80,00$ & 67,62 & 88,57 & 20,95 & Tuntas \\
\hline
\end{tabular}

KKG sangat efektif untuk meningkatkan kompetensi guru dalam penyusunan RPP yang baik dan benar bagi guru kelas 6 (enam) guru SD Negeri 10 Mataram dalam penyusunan RPP yang baik dan benar. Hal ini dibuktikan meningkatnya perolehan hasil observasi dan hasil kerja individual dari siklus I ke siklus II. Penelitian tindakan sekolah (PTS) ini dinyatakan berhasil dan dihentikan pada siklus II.

\section{SARAN}

Disarankan kepada rekan kepala sekolah lain untuk melakukan pendampingan dengan semua guru mata pelajaran dibawah binaan pada sekolah masing-masing dalam upaya meningkatkan kompetensinya khususnya dalam penyusunan RPP yang baik dan benar yang bisa diterapkan dalam proses pembelajaran di kelas senyatanya. Dampak yang diharapkan yaitu meningkatnya kualitas/mutu peserta didik di sekolah binaan melalui proses pembelajaran yang dilandasi dengan penyusunan RPP yang baik dan benar.

Kepada seluruh guru SD Negeri 10 Mataram disarankan untuk membiasakan melakukan musyawarah bersama dalam forum KKG mata pelajaran yang diampunya, khususnya dalam penyusunan RPP yang baik dan benar, sehingga berdampak meningkatnya kompetensi guru dalam proses pembelajaran di kelas senyatanya dan pada gilirannya prestasi belajar peserta didik dapat ditingkatkan.

\section{DAFTAR PUSTAKA}

Anonim, 2017, Definisi Pendampingan, dalam https://kamuspsikososial.wordpress.com/tag/ definisi-pendampingan/, diakses tanggal 13 Maret 2017 Pukul 10.45 Wita

Anonim, 2017, Pengertian Pendampingan, dalam http://www.bintans.web.id/2010/12/pengertian- pendampingan.html, diakses tanggal 13 Maret 2017 Pukul 11.04 Wita

Anonim, 2017, Kompetensi Guru, dalam https://karyono1993.wordpress.com/thesis/k ompetensi-guru/, diakses tanggal 14 Maret 2017 Pukul 11.00 wita

Anonim, 2017, Pengertian Kompetensi dan Kompetensi Guru, dalam https://mujibjee.wordpress.com/2010/01/11/ pengertian-kompetensi-dan-kompetensiguru/, di akses 14 Maret 2017 Pukul 11.26 wita

Irwan sahaja , 2017, Pengertian Kelompok Kerja Guru, dalam http://irwansahaja.blogspot.co.id/2014/08/pe ngertian-kelompok-kerja-guru-kkg.html, diakses tanggal 14 Maret 2017, pukul 20.30 Wita

Kementrian Pendidikan Nasional, 2010, Kepemimpinan Pembelajaran, Dirjen PMPTK

Keputusan Mentri Pendidikan Nasional No. 16 Tahun 2007, Standar Kualifikasi Akademik dan Kompetensi Guru.

Nana Sujana, 2009, Pendidikan Tingkat KePenelitian Konsep Dan Aplikasinya Bagi Peneliti Sekolah, Jakarta: LPP Bina Mitra.

Purnadi Pungki, M.W., 2009, KompetensiFaktor Kunci Keberhasilan, dalam http://vibizconsulting.com. Diakses tanggal 16 Agustus 2016 pukul 19.35 wita

Peraturan Pemerintah No. 19 tahun 2005 tentang Standar Nasional Pendidikan

Suharjono, 2009, Melaksanakan Sekolah Sebagai Kegiatan Penelitian Tindakan Sekolah Sebagai Kegiatan Pengembangan Profesi Penelitia Sekolah, Jakarta: Bumi Aksara.

Suharjono, 2012, Publikasi Ilmiah Dalam Kegiatan Pengembangan Keprofesian Berkelanjutan Bagi Guru, Jakarta: Cakrawala Indonesia.

Undang-Undang Republik Indonesia, No. 14 Tahun 2005 , Guru dan Dosen Daftar Pustaka

Winsolu, 2009, Pengertian Kompetensi, dalam http://my.opera.com/winsolu/blog/pengertia $\underline{\text { n-kompetensi Diakses tanggal } 16 \text { Maret } 2017}$ pukul 19.55 wita. 